\title{
Determination of some short chain carboxylic acids in food by headspace gas chromatography
}

\author{
Birutė Bugelyte், \\ Rima Jonkutè, \\ Vida Vičkačkaite் \\ Department of Analytical \\ and Environmental Chemistry, \\ Vilnius University, \\ Naugarduko St. 24, \\ 03225 Vilnius, Lithuania
}

\begin{abstract}
Headspace gas chromatographic analysis is suggested for the determination of acetic and propionic acids in aqueous media. Derivatization of the acids was accomplished by tributyl borate. The derivatization and headspace extraction were coupled into a single step. Analytical characteristics of the suggested technique at the optimized derivatization/headspace extraction conditions were determined. The technique was applied for the analysis of bakery products, ketchup, tomato paste and kefir.
\end{abstract}

Keywords: carboxylic acids, food, headspace gas chromatography

\section{INTRODUCTION}

Short chain carboxylic acids occur naturally in a number of foods, mainly in fermented products as a result of animal metabolism, hydrolysis and microbial activity during manufacture and storage. Also, organic acids are often added as food preservatives as they reduce bacterial growth by lowering the $\mathrm{pH}$ of food and thus demonstrate the antimicrobial effect [1]. For example, propionic acid serves as a preservative for bakery products and for some cheese products [2]. Propionic acid and sodium propionate are currently authorised food additives in the European Union for use in several food categories (bakery and cheese products) up to $3000 \mathrm{mg} \mathrm{kg}^{-1}$. The quantities of most other acids (acetic, lactic, malic, citric) are not limited and are allowed quantum satis [3].

Even if the quantities of the most short chain organic acids are not regulated, determination of carboxylic acids is important as the acids affect flavour, texture, aromatic properties and bacterial growth, they show antimutagenic effects, and can serve as authenticity and ageing markers 四团.

There are many methods to determine short chain organic acids in foods. If the total content of carboxylic ac-

\footnotetext{
* Corresponding author. Email: vida.vickackaite@chf.vu.lt
}

ids is of interest, traditional procedures based on titration, spectrophotometry or distillation can be employed [8]. Individual short chain carboxylic acids are determined using liquid chromatography, capillary electrophoresis and gas chromatography [1, 4 , 8.

Sometimes gas chromatographic determination of some short chain carboxylic acids is accomplished directly, however this method often suffers from poor efficiency and reproducibility and results in a rapid ageing of a chromatographic column. A much more common way is derivatization of the acids before the GC analysis. Derivatization reactions are alkylation, acylation and silylation [9-11]. Derivatized carboxylic acids are less polar compounds and thus exhibit a better gas chromatographic behaviour. Moreover, derivatization products are more volatile.

As a rule, food is a complex mixture, thus analytes should be isolated from a matrix prior to the injection to a gas chromatograph. The analytical techniques, that are applied for isolating volatile compounds, include simultaneous distillation-extraction, solvent extraction, dynamic purge and trap and headspace (HS) methods [12 16]. Headspace sampling followed by gas chromatographic analysis is the fastest and cleanest method for analysing volatile organic compounds in solid or liquid matrices [15, 17, 18]. Headspace gas chromatography (HS-GC) allows one to simplify the determination of volatile compounds by their 
isolation in the headspace of a sample vial and the subsequent automatic delivery of an aliquot of vapour to the GC system for separation [19].

The aim of the present work was to develop a simple, solvent extraction-free procedure of simultaneous derivatization and headspace gas chromatographic determination of some carboxylic acids.

\section{EXPERIMENTAL}

\section{Reagents and solutions}

Acetone ( $\geq 99.9 \%)$, hexane $(\geq 98.5 \%)$, acetic acid $(\geq 99 \%)$, oxalic acid $(\geq 99 \%)$, propionic acid $(\geq 99.5 \%)$, succinic acid $(\geq 99 \%)$, tributyl borate $(\geq 99.0 \%)$ and hydrochloric acid (36.5-38.0\%) were purchased from Sigma-Aldrich (Germany). Stock solutions of carboxylic acids (acetic, oxalic, propionic and succinic acids) $\left(1 \mathrm{mg} \mathrm{ml}^{-1}\right.$ each) were prepared in distilled water. Working solutions of carboxylic acids were prepared by dilution of the stock solutions with distilled water.

For the investigation of non-derivatized acids, working standard solutions of the acids were prepared in acetone (1 $\mathrm{mg} \mathrm{ml}^{-1}$ each).

Kefir 'Naminis' (Rokiškis), ketchup 'Felix' (Austria), tomato paste 'Favorit' (Lithuania), bread 'Ajerų' (Lithuania), croissant ' 7 days' (EU) and biscuits 'Plikyti' (Lithuania) were purchased from the local supermarket.

\section{Instrumentation and gas chromatographic conditions}

The direct gas chromatographic analysis was performed on a Shimadzu GC-2010 Plus series gas chromatograph (Shimadzu, Japan) equipped with a flame ionisation detector. The GC system was equipped with the HP- 5 capillary column $(30 \mathrm{~m} \times 0.25 \mathrm{~mm}$ id, $0.25 \mu \mathrm{m}$ film thickness) (Agilent, USA). Helium was employed as carrier gas with a constant flow of $3 \mathrm{ml} \mathrm{min}^{-1}$. The injector and detector temperature was held at $250^{\circ} \mathrm{C}$. Injection was performed in the split mode (split 10:1). The oven temperature was programmed

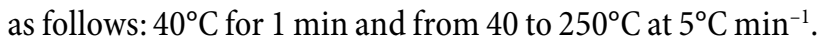

The headspace gas chromatographic analysis was performed on a PerkinElmer Clarus 580 series gas chromatograph (PerkinElmer, USA) equipped with a flame ionisation detector. The GC system was equipped with the Elite 200 capillary column $(30 \mathrm{~m} \times 0.25 \mathrm{~mm}$ id, $0.25 \mu \mathrm{m}$ film thickness) (PerkinElmer, USA). Headspace extraction and sample introduction was performed on a PerkinElmer Headspace Sampler Turbomatrix 16 (PerkinElmer, USA) equipped with a balanced pressure system.

A headspace vial with the sample and the reagents was positioned in the HS autosampler and equilibrated for $30 \mathrm{~min}$ at $95^{\circ} \mathrm{C}$. The needle temperature was $110^{\circ} \mathrm{C}$. The settings of the headspace sampler were $2 \mathrm{~min}$ for pressurization and $0.03 \mathrm{~min}$ for injection. Helium was employed as carrier gas with 15.3 psi column head pressure. The injector temperature was held at $110^{\circ} \mathrm{C}$. The detector temperature was held at $250^{\circ} \mathrm{C}$. The $\mathrm{GC}$ oven temperature was programmed as follows: $40^{\circ} \mathrm{C}$ for $1 \mathrm{~min}$ and from 40 to $250^{\circ} \mathrm{C}$ at $10^{\circ} \mathrm{C} \mathrm{min}^{-1}$.

\section{RESULTS AND DISCUSSION}

\section{Gas chromatographic determination of carboxylic acids}

There are some works on the direct GC determination of short chain carboxylic acids without their derivatization [5, 20]. Zenkevich et al. [20] suggest that derivatization is desirable or necessary for simple dicarboxylic acids but could be omitted for monocarboxylic acids. Thus, to verify the possibility of gas chromatographic determination of the analytes of interest (acetic acid, propionic acid, oxalic acid and succinic acid) without their derivatization, the solutions of the acids in acetone were directly injected into the GC system.

The results obtained (Fig. 1 and Table 1) demonstrated that the peak shapes were not acceptable. For acetic acid the peak asymmetry at $10 \%$ height was 0.561 , the peak of propionic acid was even more asymmetric (0.022). The peak of oxalic acid was also of a bad shape. Moreover, it was split so it was not possible to assess its symmetry. The peak of succinic acid was not observed at all. This preliminary examination demonstrated that derivatization of the acids was indispensable.

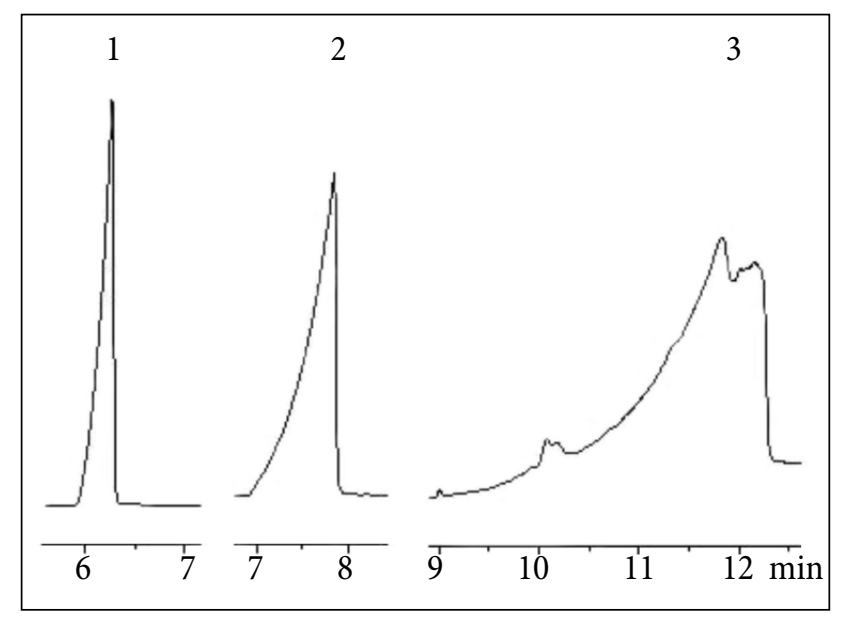

Fig. 1. Chromatograms of non-derivatized acetic (1), propionic (2) and oxalic (3) acids. Chromatographic conditions are described in the Experimental Section

Since the aim of our work was to prepare a simple, solvent extraction-free determination technique of carboxylic acids in food, the derivatization technique had to be waterinsensitive. Pervova et al. for aliphatic acids derivatization in aqueous media suggested tributyl borate as a derivatization reagent and hydrochloric acid as a catalyst [21]. We expected 
Table 1. Peak symmetry at $10 \%$ height

\begin{tabular}{ccc}
\hline & Non-derivatized & Derivatized \\
\hline Acetic acid & 0.561 & 1.033 \\
\hline Propionic acid & 0.022 & 0.870 \\
\hline Oxalic acid & - & 0.792 \\
\hline Succinic acid & - & 0.913 \\
\hline
\end{tabular}

that butyl esters of the acids obtained during the derivatization process should be sufficiently volatile for headspace gas chromatographic determination.

The derivatization procedure suggested in [21] was slightly modified and carried out at $95^{\circ} \mathrm{C}$ instead of $100^{\circ} \mathrm{C}$ in order to adapt the derivatization method to the headspace gas chromatographic analysis. The maximum allowable sample heating temperature in headspace gas chromatography depends on the solvent's nature as the solvent's vapour mainly determines the pressure in the headspace. If the pressure is too high, some instrumental problems may occur, the vial may cause leakage or even break [19]. As the main solvent in foods is usually water, in order to not exceed solvent's vapour pressure the sample heating temperature should not exceed $95^{\circ} \mathrm{C}$.

Derivatization conditions were examined using the aqueous solutions of the analytes. For the derivatization, $0.1 \mathrm{ml}$ of an aqueous analyte solution, $1 \mathrm{ml}$ of tributyl borate and $0.1 \mathrm{ml}$ of concentrated $\mathrm{HCl}$ were sealed and heated at $95^{\circ} \mathrm{C}$ temperature for $40 \mathrm{~min}$. Then the derivatization products were extracted with $1 \mathrm{ml}$ of hexane and the hexane phase was injected into the Shimadzu GC for analysis.

The results presented in Fig. 2 and Table 1 demonstrated that the shapes and symmetry of derivatized acids significantly improved.

\section{Optimization of headspace gas chromatographic conditions}

The next step of the work was to examine the possibility to determine the analytes of interest by headspace gas chro- matography. This method seems to be especially attractive due to the possibility to couple derivatization and headspace extraction steps.

A derivatization procedure was carried out in a sealed headspace vial placed in a headspace sampler oven at $95^{\circ} \mathrm{C}$ temperature. Simultaneously a transfer of volatile derivatization products to the headspace occurred. The equilibrium distribution of the compounds between the sample phase and the gas phase is defined by the temperature dependent partition coefficient. Samples should be prepared to maximize the concentration of volatile components in the headspace (i.e. to minimize the partition coefficients). The partition coefficient can be lowered (i.e. the concentration of analytes in the headspace can be increased) by increasing the temperature at which the vial is heated. In our case the maximum allowable temperature that did not exceed the boiling point of the main matrix component (water) was applied.

Unfortunately, the peaks of oxalic and succinic acids butyl esters were absent in the chromatograms. Probably their volatility at the selected temperature was too low to be detected by headspace gas chromatography. Thus, further investigation was carried out on two acids - acetic and propionic.

The time necessary to derivatize the carboxylic acids and to simultaneously reach the equilibrium of the derivatized analytes between the sample and the headspace was determined. The derivatization/equilibration time up to $40 \mathrm{~min}$ has been investigated. As seen in Fig. 3, the peak areas of the analytes levelled off after $30 \mathrm{~min}$. The optimum derivatization/equilibration time of $30 \mathrm{~min}$ was therefore chosen to achieve the maximum sensitivity without extending the time of analysis.

For the aqueous solutions containing acetic and propionic acids, quality parameters such as linearity, limits of detection and repeatabilities were determined under the optimized conditions. The calibration curves were drawn with 7 calibration points with three replicate injections. The limits

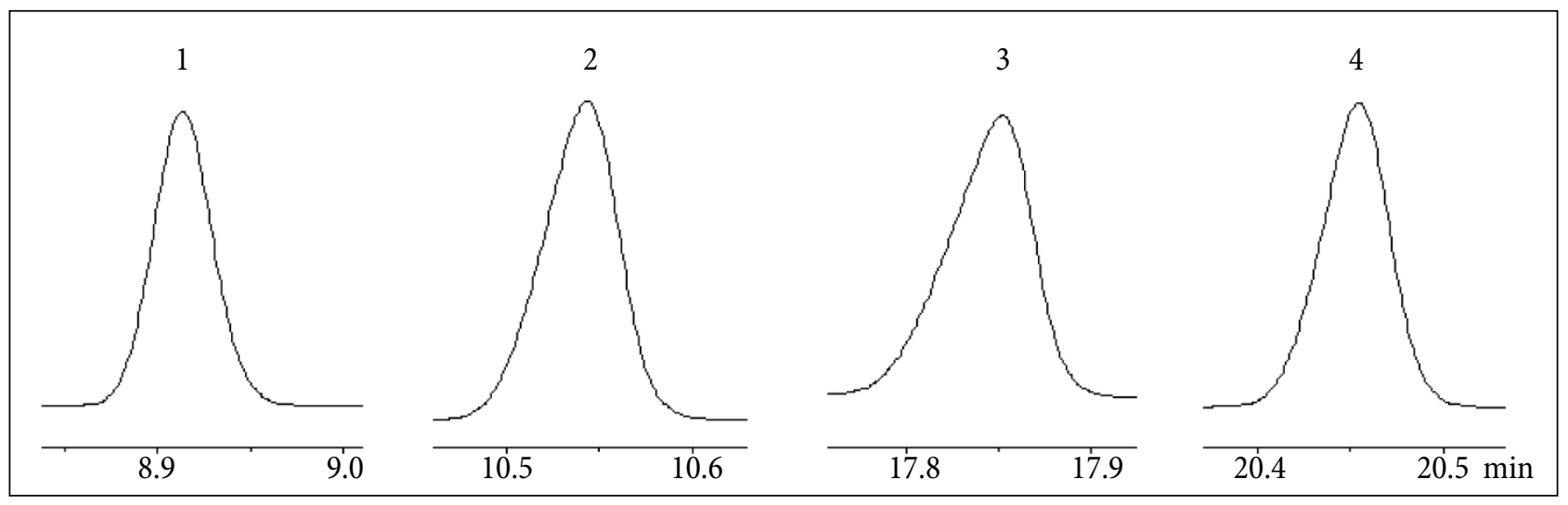

Fig. 2. Chromatograms of tributyl borate derivatized acetic (1), propionic (2), oxalic (3) and succinic (4) acids. Chromatographic conditions are described in the Experimental Section 


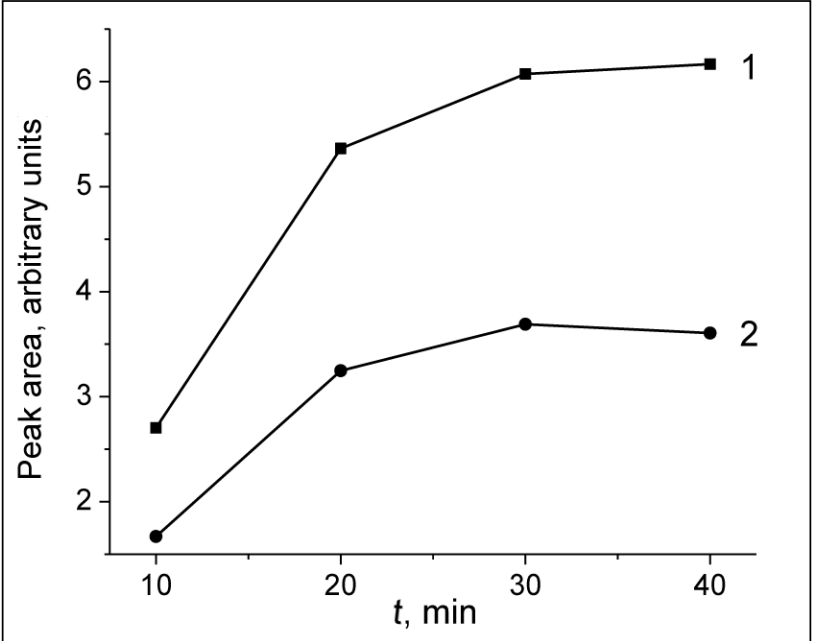

Fig. 3. The influence of extraction time on the headspace extraction efficiency of acetic (1) and propionic (2) acid derivatives. Extraction temperature $95^{\circ} \mathrm{C}$, pressurization time $2 \mathrm{~min}$, injection time $0.03 \mathrm{~min}$ of detection (LOD) were defined as three times the baseline noise. The repeatabilities were determined by five repetitions analysis of the analytes. The linear ranges, correlation coefficients, limits of detection and relative standard deviations are presented in Table 2.

\section{Real sample analysis}

The prepared headspace gas chromatographic technique was applied for the determination of acetic and propionic acids in food samples. Kefir, ketchup, tomato paste, and three bakery products have been analysed. $0.2-0.37 \mathrm{~g}$ of the sample were weighted for the analysis, the sample was placed into a headspace vial, $1 \mathrm{ml}$ of tributyl borate and $0.1 \mathrm{ml}$ of concentrated $\mathrm{HCl}$ was added, the vial was sealed and the analysis were carried on as described above.

The chromatograms of non-derivatized and derivatized kefir evidenced the appearance of the peaks of acetic acid and propionic acid butyl esters after derivatization (Fig. 4).

\section{Table 2. Analytical characteristics}

\begin{tabular}{|c|c|c|c|c|}
\hline Analyte & Linear range, $\mathrm{gl}^{-1}$ & $\mathbf{R}^{2}$ & LOD, $\mathrm{mg} \mathrm{I}^{-1}$ & RSD, $\%\left(\right.$ at $\left.0.05 \mathrm{moll}^{-1}\right)$ \\
\hline Acetic acid & $0.002-0.5$ & 0.997 & 0.9 & 2.5 \\
\hline Propionic acid & $0.005-0.5$ & 0.995 & 3.0 & 3.4 \\
\hline
\end{tabular}

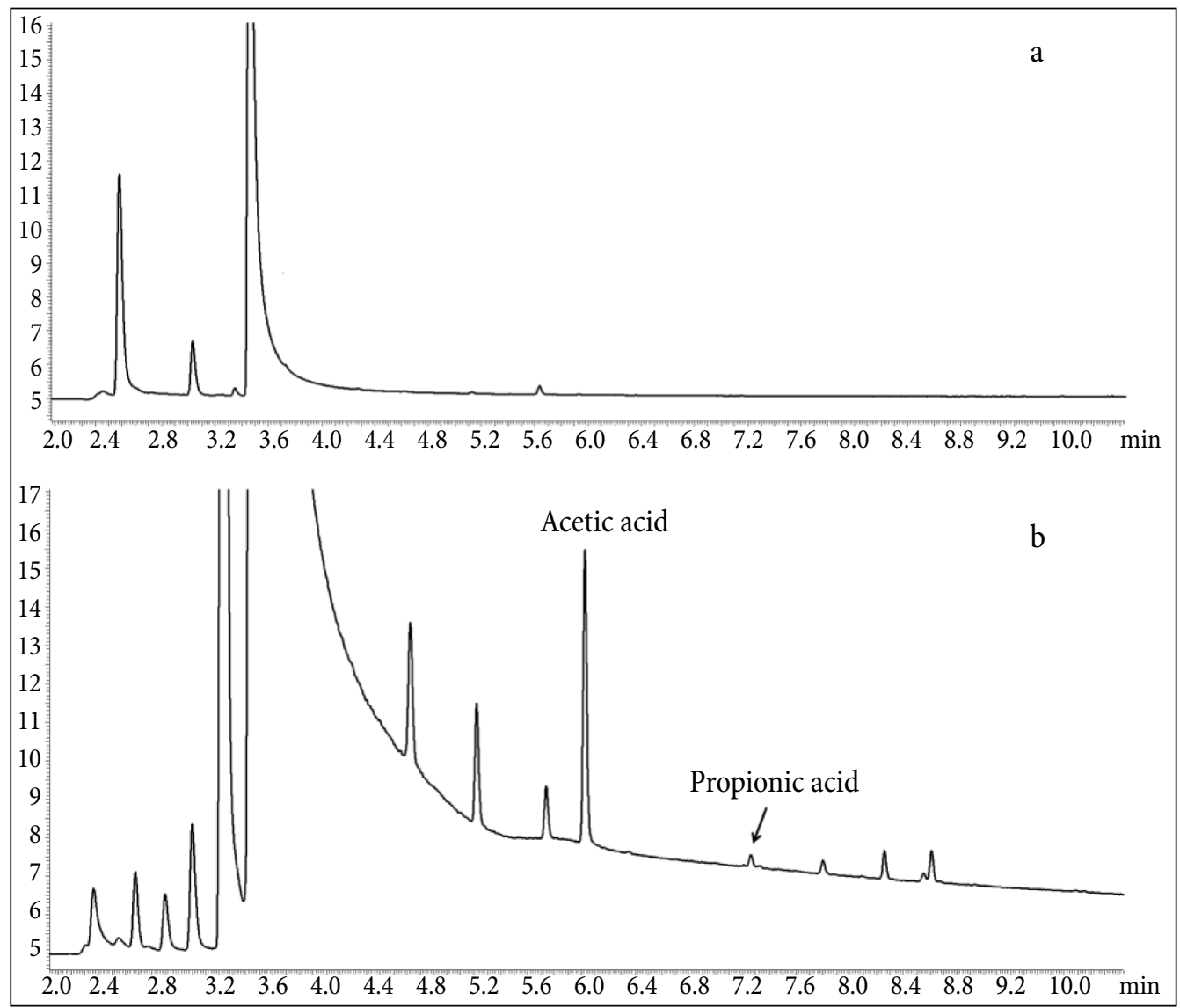

Fig. 4. The chromatograms of non-derivatized (a) and derivatized (b) kefir. Chromatographic conditions are described in the Experimental Section. 
The results of the analyses are presented in Table 3. Acetic acid was determined in all the examined samples. In the European Union the amount of acetic acid is not regulated, the allowable amount should be sufficient to reach the required pH. Propionic acid was present in kefir, croissant and biscuits. The biggest amount of propionic acid was detected in the croissant sample. The croissant was the only product for which the concentration of calcium propionate was indicated by producers $(<0.1 \%)$. This is consistent with the results obtained. The biscuit label says that calcium propionate has been added, but its content is not indicated. Anyway, its content does not exceed the permissible rate of $2000 \mathrm{mg} \mathrm{kg}^{-1}$ for confectionery [3].

Table 3. Results of real sample analysis, $\mathbf{g ~ k g}^{-1}(n=3)$

\begin{tabular}{ccc}
\hline & Acetic acid & Propionic acid \\
\hline Kefir & $1.8 \pm 0.1$ & $0.14 \pm 0.01$ \\
\hline Ketchup & $7.8 \pm 0.4$ & - \\
\hline Tomato paste & $2.4 \pm 0.1$ & - \\
\hline Bread & $3.9 \pm 0.2$ & - \\
\hline Croissant & $1.2 \pm 0.1$ & $0.83 \pm 0.05$ \\
\hline Biscuits & $1.1 \pm 0.1$ & $0.49 \pm 0.03$ \\
\hline
\end{tabular}

\section{CONCLUSIONS}

The investigation revealed that the peaks of non-derivatized carboxylic acids were asymmetric, thus before the gas chromatographic analysis derivatization of the acids is indispensable. The derivatization with tributyl borate was selected as it was reported to be water-insensitive and thus suitable for food samples without pre-extraction of the acids to the organic phase. Moreover, derivatization conditions are compatible with headspace extraction conditions, thus it is possible to couple derivatization and headspace extraction steps. The simultaneous derivatization/headspace gas chromatographic method was successfully applied for the determination of acetic and propionic acids in kefir, ketchup, tomato pasta and some bakery products. Unfortunately, butyl esters of oxalic and succinic acids were not detected probably because their volatility at the selected temperature was too low to be transferred to the headspace.

Further work is underway, changing the derivatization reagent and operating conditions in order to accomplish the simultaneous derivatization/headspace extraction step of dicarboxylic and tricarboxylic acids.

Received 19 June 2018 Accepted 27 June 2018

\section{References}

1. M. Pereira da Costa, C. A. Conte-Junior, Compr. Rev. Food Sci. Food Saf., 14, 586 (2015).
2. H.-J. Lee, H.-J. Ahn, C.-S. Kang, J.-C. Choi, H.-J. Choi, K.- G. Lee, J.-I. Kim, H.-Y. Kim, Food Control, 21, 217 (2010).

3. Regulation (EC) No 1333/2008 of the European Parliament and of the Council of 16 December 2008 on food additives, OJ L 354, pp. 16-33, 31.12.2008.

4. G. Turker, B. Kizilkaya, N. Arifoglu, Asian J. Chem., 26, 2443 (2014).

5. M.-H. Yanga, Y.-M. Choong, Food Chem., 75, 101 (2001).

6. A. M. S. Sant'Ana, J. E. S. Ribeiro, F. F. Bezerril, F. L. H. Silva, M. S. Madruga, R. C. R. E. Queiroga, Rev. Mex. Ing. Quím., 16, 781 (2017).

7. M. Cocchi, C. Durante, M. Grandi, P. Lambertini, D. Manzini, A. Marchetti, Talanta, 69, 1166 (2006).

8. R. Fernández, R. M. Dinsdale, A. J. Guwy, G. C. Premier, Crit. Rev. Environ. Sci. Technol., 46, 209 (2016).

9. M. C. Pietrogrande, D. Bacco, M. Mercuriali, Anal. Bioanal. Chem., 396, 877 (2010).

10. P. Hušek, P. Šimek, P. Matucha, Chromatographia, 58, 623 (2003).

11. M. A. Farajzadeh, N. Nouri, P. Khorram, TRAC, 55, 14 (2014).

12. G. Arora, F. Cormier, B. Lee, J. Agric. Food Chem., 43, 748 (1995).

13. L. Alonso, M. J. Fraga, J. Chromatogr. Sci., 39, 297 (2001).

14. Z. Guker, A. Tasdelen, H. Senol, N. Kerimoglu, U. Temel, GIDA, 34(3), 137 (2009).

15. A. Arezou, M. Shuhaimi, A. M. Yazid, M. Rosfarizan, Int. J. Food Prop., 12, 808 (2009).

16. U. Ravid, M. Elkabetz, C. Zamir, K. Cohen, O. Larkov, R. Aly, Flavour Frag. J., 25, 20 (2010).

17. H. Cheng, Crit. Rev. Food Sci., 50, 938 (2010).

18. V. Vičkačkaitè, D. Jasas, Chemija, 27(2), 109 (2016).

19. B. Kolb, L. S. Ettre, Static Headspace-Gas Chromatography: Theory and Practice, 2nd edn., Wiley, New Jersey (2006).

20. I. G. Zenkevich, L. N. Fakhretdinova, J. Anal. Chem., 71, 402 (2016).

21. M. G. Pervova, D. L. Chizhov, V. I. Saloutin, J. Anal. Chem., 71, 1041 (2016).

Birutė Bugelytė, Rima Jonkutė, Vida Vičkačkaitė

\section{KAI KURIŲ KARBOKSIRŪGŠČIŲ}

\section{NUSTATYMAS MAISTO PRODUKTUOSE DUJŲ CHROMATOGRAFINĖS VIRŠERDVĖS ANALIZĖS METODU}

\section{Santrauka}

Acto ir propiono rūgštims vandeninejje terpejje nustatyti pasiūlyta dujų chromatografinè viršerdvès analizė. Rūgštys buvo derivatizuotos tributilboratu. Derivatizacija buvo sujungta su ekstrakcija i viršerdvę. Optimizuotomis derivatizacijos / viršerdvès ekstrakcijos sąlygomis buvo nustatytos pasiūlyto metodo analizinès charakteristikos. Metodas pritaikytas analizuoti kepinius, kečupą, pomidorų pastą ir kefyrą. 